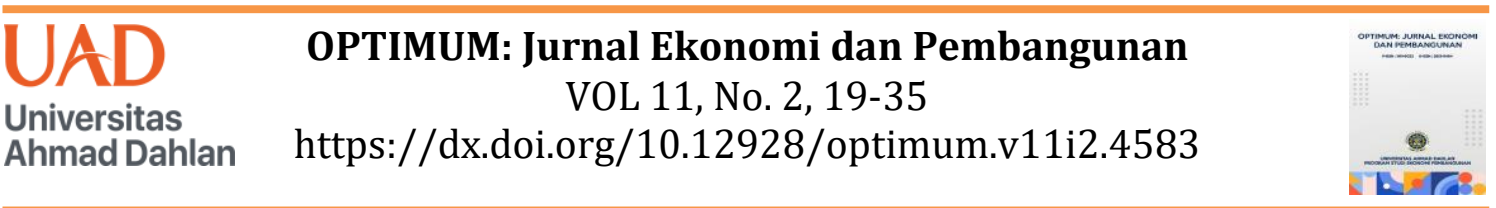

\title{
Inclusive Growth in Northern and Southern Central Java
}

\author{
Hayu Wuranti ${ }^{1, a *}$ \\ 1 hayu@bps.go.id \\ aBPS Provinsi JawaTengah \\ *corresponding author
}

\section{ARTICLE INFO \\ ABSTRACT}

Article history

Received : 30-07-2021

Revised : 21-08-2021

Accepted : 23-08-2021

Keywords

Inclusive Growth

Inequality

Poverty
Inclusive growth is one of the visions of sustainable development. The economic growth of a region is said to be inclusive if it is can reduce poverty, reduce inequality and absorb more labour. Central Java is one of the regions with fairly high economic growth but has various social problems. Therefore, this study wants to analyze the inclusiveness of economic growth in the North and South Central Java region. The research is based on data from 35 districts in Central Java, which adopts the concept formulated by Klasen (2010) regarding the PovertyEquivalent Growth Rate (PEGR). The research shows that during the 2018-2020 period, Central Java has inconsistent inclusive growth. Meanwhile, inclusive growth for reduce poverty, reduce inequality and absorb more labour in 2018 mostly occurred in the northern part of Central Java but was more and more balanced.

This is an open access article under the CC-BY-SA license.

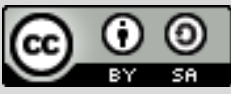

\section{Introduction}

Suryanarayana (2013) states that one of the visions of sustainable development is inclusive growth, which includes increasing production, income, and distribution of income/expenditures. According to Klasen (2010), inclusive growth is growth that is able to provide access and is non-discriminatory to all parties and is can reduce inequality. The growth of a region is said to be inclusive, not only seen from high economic growth but also can be seen from the low level of poverty, equitable income inequality, and high levels of labour. ADB (2011) revealed the background to the realization of inclusive growth among others: (1) growth must be distributed and inclusive at all levels of society and regions as a form of equality and justice; (2) growth, which is still accompanied by inequality, creates a domino effect on social problems, such as the vulnerability of the poor and unemployed to crime, the vulnerability of women to prostitution and the emergence of child labour problems; (3) sustainable growth potential can be reduced if political stability and social 
structure hampered due to inequality access and growth results.

The selection of North and South Central Java became the locus of this research, with various considerations, including the current Central Java provincial government is developing the northern part of Central Java and southern Central Java. This is stated in the Final Draft of the 2018-2023 RPJMD (Central Java Governor Regulation Number 5 of 2019). One of the general policies in the direction of regional development is the North-South development axis to reduce regional economic inequality. Based on the results of the Location Quotient (LQ) analysis conducted by Ahmad and Kamio (2009), the map of the manufacturing industry with a low level of industrial competition and no potential, is dominated by regencies in the Southern Central Java region. Trenasia.com (2020) states that the development of an industrial area that focuses on the North Central Java region gives the impression of an imbalance between the northern and southern Central Java regions. Therefore, we need to analyze how the level of inclusiveness of growth in the two regions is.

There have been many studies related to inclusive growth in Indonesia using different measurement methods. Several studies on inclusive growth using the method adopted from McKinley (2010) in the Asian Development Bank (ADB) including Ramadhan and Setiadi (2019) in Indonesia, Hapsari (2019) in Central Java, Kusumaningrum and Yuhan (2019) in Indonesia, Long and Pasaribu (2019) in Central Java, Pratama et al (2020) in Jambi and Purba et al (2020) in South Sumatra while the studies was using the formula Klasen (2010) by adopting the concept of Poverty-Equivalent Growth Rate (PEGR) had been carried out by Amalina et al (2013) in Indonesia territory of Western and Eastern Indonesia territory, Sholihah (2014) in Indonesia, Azwar (2016) in South Sulawesi, Cahyadi et al (2018) in Bali, Bado et al (2019) in South Sulawesi, Purwanti and Rahmawati (2019) in Indonesia and Satrio et al (2019) in West Sumatra. Meanwhile, Sitorus and Arsani (2019) compare the calculation results from 3 different methods, namely the method adopted from ADB, WEF and UNDP by taking research locus in the Indonesian. Munir \& Ullah (2018) used the Social Mobility Curve method in Pakistan to look at inclusive growth and panel data regression to see the factors that influence inclusive growth in developing countries. Dirgantoro et al. (2009), Prasetyo et al. (2013), Nur et al. (2013), Wahyuni et al. (2014), Wibowo (2014), Sungkar et al. (2015), Sukanto (2015), Sipahutar et al. (2016), Quy (2016) and Rambeli et al. (2016), Anwar (2017) and Hidayat et.al (2020) used the Two-Stage Least Square (2SLS) method. Research related to inclusive growth with other methods was also carried out by Rindayati et al (2007), Lisna et al (2013), Warsilah (2015), Wirawan and Arka (2015), Sulistyowati et al (2017), Nalle (2018), Hidayat (2020) and Fitri (2021). 
Although there have been many studies on inclusive growth, but research on inclusive growth that compares the North Central Java region and the South Central Java region has never been conducted. The regional division in this study refers to the Central Java Governor Regulation Number 5 of 2019. The objectives of this study include analyzing (1) inclusive economic growth in Central Java; (2) Consistency of inclusive economic growth in Central Java; (3) Comparison of inclusive economic growth between the northern and southern parts of Central Java.

\section{Method}

\section{Data Types and Sources}

The calculation of inclusive growth uses data from BPS, namely Gross Regional Domestic Product (GRDP) at Constant Prices, the number of poor people, the Gini coefficient, per capita income which is approximated by per capita expenditure data, the number of working people and the labour force. These data can be accessed through the website jateng.bps.go.id. Research on inclusive growth with similar data at different locus has also been carried out by Amalina et al (2013) and Basri et al (2019). The data used in this study are the latest data, namely 2017-2020, for calculating inclusive growth in 2018-2020. The initial data used is 2017 data because data related to the number of working population and labour force in 2016 is not available until the district level. This was due to the 2016 National Labour Force Survey (Sakernas) data which is insufficient for analysis at the district level. The northern and southern regions of Central Java in this study refer to the Central Java Governor Regulation Number 5 of 2019.

Table 1. Regional Division according to Central Java Governor Regulation Number 5 of 2019

\begin{tabular}{lllll}
\hline \multicolumn{3}{c}{ Northern Central Java } & \multicolumn{3}{c}{ Southern Central Java } \\
\hline Brebes, Kota Tegal, Kabupaten Tegal, & Banjarnegara, Purbalingga, & Banyumas, \\
Pemalang, Kabupaten Pekalongan, Batang, & Cilacap, Kebumen, Purworejo, Kabupaten \\
Kota Pekalongan, Kendal, Demak, Kabupaten & Magelang, Kota Magelang, Wonosobo, \\
Semarang, Salatiga, Kota Semarang, & Temanggung, Surakarta, Boyolali, Sukoharjo, \\
Grobogan, Jepara, Kudus, Pati, Rembang, & Karanganyar, Wonogiri, Sragen, Klaten \\
Blora
\end{tabular}

Source : Central Java Governor Regulation Number 5 of 2019

\section{Analysis Method}


The analytical method which is used to answer the problems in this study is a descriptive analysis method with a quantitative approach, where after the research data is processed using Excel and SPSS software an analysis is carried out to draw conclusions so that an overview of the object being studied is obtained. According to Sugiyono (2014:21), descriptive statistical analysis methods are used by describing or describing the data that has been collected with conclusions that are not general or generally accepted.

\section{Inclusive Growth Measurement Method}

To calculate the effect of increasing economic growth on decreasing the number of poor people, decreasing income inequality and increasing labour, using the analytical method developed by Klasen (2010), namely the Poverty-Equivalent Growth Rate (PEGR) method. The measurement of inclusive growth using a similar method has been carried out in the studies of Amalina et al (2013), Sholihah (2014), Azwar (2016), Cahyadi et al (2018), Basri et al (2019) and Purwanti and Rahmawati (2019).

Growth Inclusive Natural in Reducing Poverty

Amalina et al (2013) formulate the calculation with the following formula:

$$
\mathbf{I G}_{\boldsymbol{p}}=\left(\frac{G_{p g}}{G_{p}}\right) \hat{\mathrm{G}}_{\boldsymbol{g}}
$$

Where $I G_{p}$ is coefficient of inclusive growth in reducing poverty; $G_{p}$ is elasticity of poverty to average income; $G_{p g}$ is the elasticity of poverty on economic growth; $\hat{G}_{g}$ is coefficient of economic growth.

$\mathrm{IG}_{\mathrm{p}}$ is a measure of inclusiveness in reducing poverty, which is stated inclusive growth if $I G_{p}>G_{g}$ (coefficients inclusive growth to reduce poverty is greater than coefficients of economic growth). To calculate elasticity is using the same way with the PEGR concept. The elasticity of poverty to average income $(\mathrm{Gp})$ can be calculated as:

$$
G_{p}=\frac{\mathrm{P}_{12}}{\Psi}
$$

$\mathrm{P}_{12}$ is the percentage change in the number of poor people in period 1 and period 2 can be calculated as:

$$
P_{12}=P_{2}-P_{1}=\operatorname{Ln}\left[\mathrm{P}\left(Z_{2}, X_{2}\right)\right]-\operatorname{Ln}\left[\mathrm{P}\left(Z_{1}, X_{1}\right)\right]
$$

where $\mathrm{P}(\mathrm{Z}, \mathrm{X})$ is a function of the number of poor people $(\mathrm{Z})$ and the average income of the population $(\mathrm{X})$.

$\Psi$ is the percentage change in the average income of the population can be calculated as:

$$
\Psi=\operatorname{Ln}\left(X_{2}\right)-\operatorname{Ln}\left(X_{1}\right)
$$

The poverty elasticity of economic growth $(\mathrm{Gpg})$ can be calculated as: 


$$
G_{p g}=\frac{\mathrm{P}_{12}}{\hat{\mathrm{G}}_{g}}
$$

Where $\hat{\mathrm{G} g}$ is the coefficient of economic growth is calculated as the change in Gross Regional Domestic Product (GDP) in a period, so that economic growth can be written as follows:

$$
\hat{\mathrm{G}}_{g}=\operatorname{Ln}\left(\mathrm{GDP}_{2}\right)-\operatorname{Ln}\left(\mathrm{GDP}_{1}\right)
$$

Inclusive Growth in Reducing Inequality

The calculations formulated by Amalina et al (2013) are:

$$
\mathrm{IG}_{\text {in }}=\left(\frac{G_{\text {in. }}}{G_{\text {in }}}\right) \hat{\mathrm{G}}_{g}
$$

Where $I G_{\text {in }}$ is coefficient of inclusive growth in reducing inequality; $G_{\text {in }}$ is inequality elasticity of average income; $G_{\text {in.g }}$ is elasticity of inequality to economic growth; $\hat{G}_{g}$ is coefficient of economic growth.

IG $\mathrm{n}$ is a measure of inclusiveness in reducing inequality which is stated inclusive growth if the IGin > Gg (coefficients inclusive growth in reducing inequality is greater than coefficients economic growth).

The inequality elasticity of average income (Gin) can be calculated as:

$$
G_{\text {in }}=\frac{\mathrm{In}_{12}}{\Psi}
$$

Where $\operatorname{In}_{12}$ is the change in inequality in period 1 and period 2 can be calculated as:

$$
I n_{12}=I n_{2}-\operatorname{In} n_{1}=\operatorname{Ln}\left[\operatorname{In}\left(G I N I_{2}, X_{2}\right)\right]-\operatorname{Ln}\left[\operatorname{In}\left(G I N I_{1}, X_{1}\right)\right]
$$

Where In (inequality) is a function of the Gini index (GINI) and the average income of the population $(\mathrm{X})$, which is written as follows:

$$
\text { In }=\operatorname{Ln}(\mathrm{GINI}, \mathrm{X})
$$

The elasticity of inequality to economic growth (Gin.g) can be calculated as:

$$
G_{\text {in.g }}=\frac{\mathrm{In}_{12}}{\hat{\mathrm{G}}_{g}}
$$

Growth Inclusive in Enhancing Labour Abrsoption

According to Amalina et al (2013) the calculation is done by:

$$
\mathrm{IG}_{e m}=\left(\frac{G_{e m . g}}{G_{e m}}\right) \hat{\mathrm{G}}_{g}
$$

Where $\mathrm{IG}_{\mathrm{em}}$ is coefficient of inclusive growth in absorbing labour; $\mathrm{G}_{\mathrm{em}}$ is labour absorption elasticity; $G_{\text {em.g }}$ is elasticity of labour to economic growth; $G_{g}$ is coefficient of economic growth.

$\mathrm{IG}_{\mathrm{em}}$ is the inclusiveness of growth in absorbing labour, so that growth is declared inclusive if the $I_{\text {em }}$ value $>G_{g}$ (coefficient of inclusive growth in absorbing labour is greater than the coefficient of economic growth). 
The elasticity of labour to the labour force (Gem) can be calculated as:

$$
G_{e m}=\frac{\mathrm{Em}_{12}}{\mathrm{AK} *}
$$

Where $\mathrm{Em}_{12}$ is change in the percentage of labour absorption in period 1 and period 2 can be calculated as:

$$
E m_{12}=E m_{2}-E m_{1}=\operatorname{Ln}\left[E m\left(\text { Worker }_{2}, A K_{2}\right)\right]-\operatorname{Ln}\left[E m\left(\text { Worker }_{1}, A K_{1}\right)\right]
$$

With Em (labour absorption) is a function of the number of people working (Worker) and the number of labour force (AK), which is written as follows:

$$
E m=\text { Em(Worker, } \mathrm{AK})
$$

$\mathrm{AK}^{*}$ is change in the percentage of the workforce can be calculated as:

$$
A K *=\operatorname{Ln}\left(\mathrm{AK}_{2}\right)-\operatorname{Ln}\left(A K_{1}\right)
$$

The elasticity of labour absorption on economic growth (Gem.g) can be calculated as:

$$
G_{\mathrm{em} \cdot g}=\frac{\mathrm{Em}_{12}}{\hat{\mathrm{G}}_{g}}
$$

\section{Result and Discussion}

Economic growth is said to be inclusive if the growth is able to make an impact on people's welfare. Inclusive growth can be proven if it can reduce the level of poverty, reduce income inequality and increase labour. In this study, inclusive analysis is divided into several sub-discussions. The first discussion is related to inclusiveness in Central Java and its consistency. The next three sub-discussions describe the level of inclusiveness of growth in each indicator, namely poverty, inequality and labour. The next section discusses the comparison of inclusiveness levels in Northern and Southern Central Java.

\section{Inclusiveness Growth Economy Java Central}

Figure 1 shows that the level of inclusiveness in Central Java during the 2018-2020 period is inconsistent, both in reducing poverty, reducing inequality and employment. This can be seen from the value of the inclusiveness coefficient on the three sizes which tend to fluctuate. Inclusiveness towards reduction of poverty occurred in the year 2018, evidenced by the value of the coefficient of inclusive language that was more substantial when compared to the value of the coefficient of growth of the economy. Although the inclusive coefficient value in reducing poverty in 2019 was positive because it was smaller than the coefficient of economic growth, meaning that poverty reduction will continue to occur in line with increasing economic growth, but most of the benefits were still enjoyed by nonpoor people. There in 2020, the value of the coefficient of reduction of poverty and the coefficient of growth of the economy were equally worth negative, but the value of the coefficient of growth of the economy was smaller than the coefficient of reduction of poverty 
. It is demonstrated that the decline in the growth of the economy in the year 2020 was small when compared to the increase in the number of the population was poor .

Meanwhile, Figure 1 also shows that during the period 2018-2020 there was no inclusiveness towards reducing inequality. This was evidenced by the coefficient inclusive of the decline in inequality during that period, much lower if compared to the coefficients of the growth of the economy. In 2018, the inclusiveness coefficient on inequality was negative, meaning that existing economic growth tends to increase inequality. Meanwhile in 2019 , the inclusive coefficient on inequality was positive but it was still lower than the economic growth coefficient, indicating that the benefits of economic growth were not evenly distributed causing inequality. Meanwhile, in 2020, the growth coefficient was negative, meaning that the economic growth that occurs was not able to reduce inequality, and even tends to exacerbate the inequality in the distribution of people's income .

Things are different shown by the coefficient of absorption of labour labour, where the value is fluctuating. This can be seen in Figure 1. In the year 2018, the coefficient inclusive of the labour had a value that was equal to the coefficient of growth of the economy, which indicates that the increase in the growth of economy was comparable with the absorption of energy work . Meanwhile, in 2019 the inclusive coefficient of labour was positive but smaller than the coefficient of economic growth, which means that although economic growth was able to absorb labour, the increase in economic growth was slower than the increase in labour absorption . Coefficient growth of the economy in 2020 worth negative, that can be said economic growth is happening, unable to create new jobs or even aggravate the number of open unlabour .

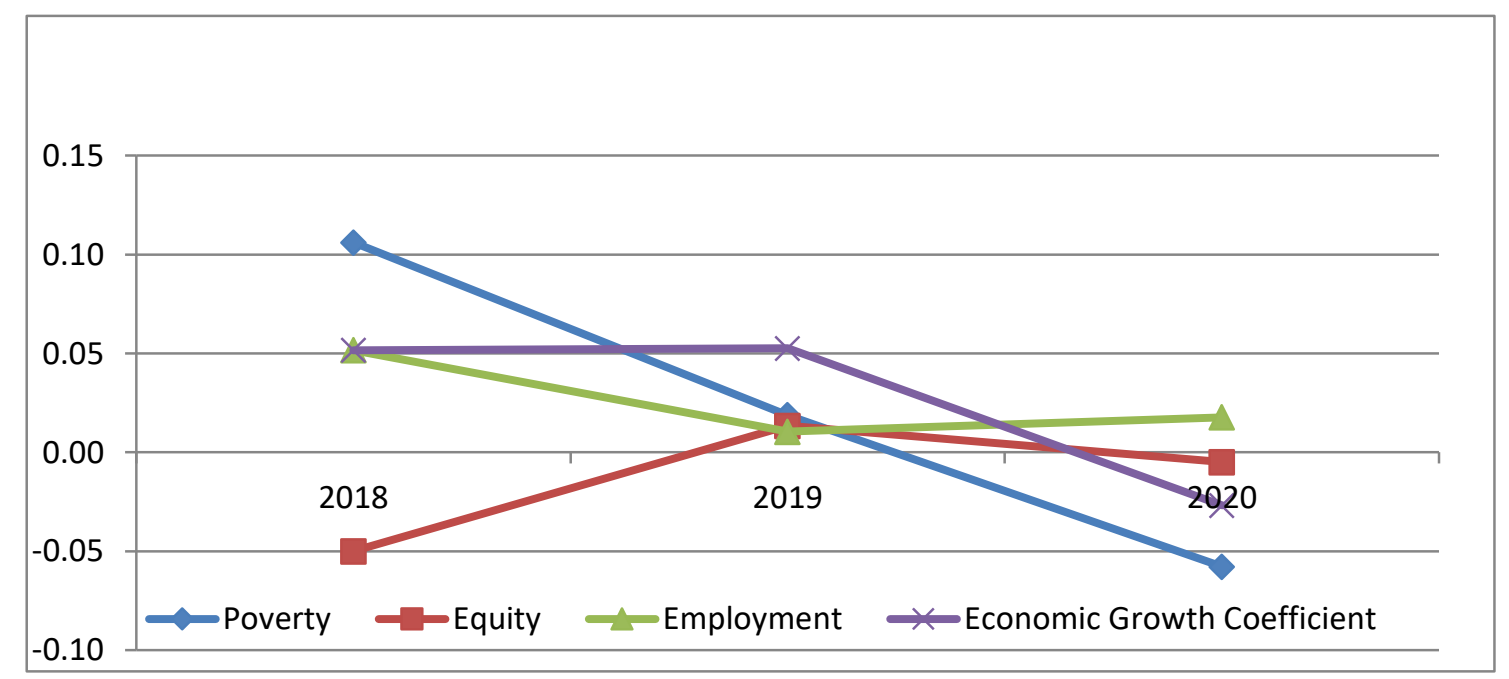

Source: Inclusive Index Coefficient Processing Results

Figure 1. The Inclusiveness Coefficient of Poverty Reduction, Decreasing Equity, Labour Absorption and Economic Growth Coefficient in Central Java , 2018-2020 
This study shows the same results as previous studies. Using the same calculation methodology, Amalina et al (2013) in their research stated that the inclusiveness of economic growth in reducing poverty, reducing inequality, and increasing labor absorption in Indonesia in 2008-2012 has not been consistent. The same thing was stated by Iskandar (2016) in South Sulawesi in 2011-2014.

\section{Economic Growth Inclusiveness in Reducing Poverty}

One of the rejected measure growth inclusive is can reduce poverty. Inclusivity in reducing poverty in this study can be seen from the value of the coefficient of inclusiveness to poverty (IGP) . The results of the Inclusive Index Coefficient Processing show that the number of districts/cities in Central Java with inclusive growth in reducing poverty in 2018 is more than in 2019. This can be seen from the increasing number of districts in Central Java that were able to maintain inclusiveness in reducing poverty, including Cilacap, Banjarnegara, Magelang, Sukoharjo, Rembang, Jepara, Demak and Kendal. But there were also districts that year before non inclusive growth to reducing poverty, precisely in 2019 turned into an inclusive, namely : Kebumen, Blora, Temanggung and Magelang City. While in 2020, the entire districts have value of the coefficient of growth of negative economic. It was meaningful in 2020, the growth of the economy which was occurred did'nt afford to lower poverty and even tend to the poverty level was getting higher .

\section{Economic Growth Inclusiveness in Reducing Inequality}

Indicators another in the growth of inclusive is the ability of economic growth in reducing inequality. Inclusive growth is said to reduce inequality if economic growth can be enjoyed by all people. Based on the results of the Inclusive Index Coefficient Processing, in 2018 , only 8 districts/cities whose growth was not inclusive of poverty reduction. Contrast with condition of the previous year, in 2019, it was only 12 districts had a growing inclusive to the reduction of inequality, namely: Cilacap, Banjarnegara, Kebumen, Magelang, Sukoharjo, Blora, Rembang, Jepara, Demak, Kendal and Magelang City. All districts in Central Java in 2020 had a negative growth coefficient, which means that the economic growth that occurs is unable to carry out its role in reducing inequality, even widening existing inequality.

\section{Inclusiveness of Economic Growth in Labour Absorption}

The third indicator of inclusive growth is being able to absorb more labour. Economic growth is said to be inclusive of labour if the coefficient of inclusive growth of labour (IGem) is greater than the coefficient of economic growth (Gg). From the results of the Inclusive Index Coefficient Processing, it can be seen that there are only 4 districts/cities that have inclusiveness in employment in 2018, namely Wonogiri, Blora, Demak and Magelang City. A 
year later the number decreased to only 2 districts are Cilacap and Tegal City. In 2020, economic growth in all districts will not be able to absorb more workers, and even tend to increase unlabour. This can be seen from the negative economic growth coefficient in all districts.

\section{Comparison of Economic Growth Inclusiveness in North and South Central Java}

The inclusiveness coefficient of an indicator in a region can change from year to year. This also happened in the northern part of Central Java and southern Central Java, as shown in Figure 2. Judging from the level of inclusiveness towards poverty reduction in 2018, all districts in northern Central Java had inclusive growth, while the southern part of Central Java only 70,59\% districts had inclusive growth. Meanwhile, in 2019, both in the northern and southern parts of Central Java, the number of districts that had inclusive growth towards poverty was balanced. However, in the following year 2020, there are no districts/cities in both north and south Central Java whose growth is inclusive of poverty reduction. This was caused by the coefficient of economic growth in all districtss negative, because economic growth was affected by the COVID-19 pandemic.

Source: Inclusive Index Coefficient Processing Results

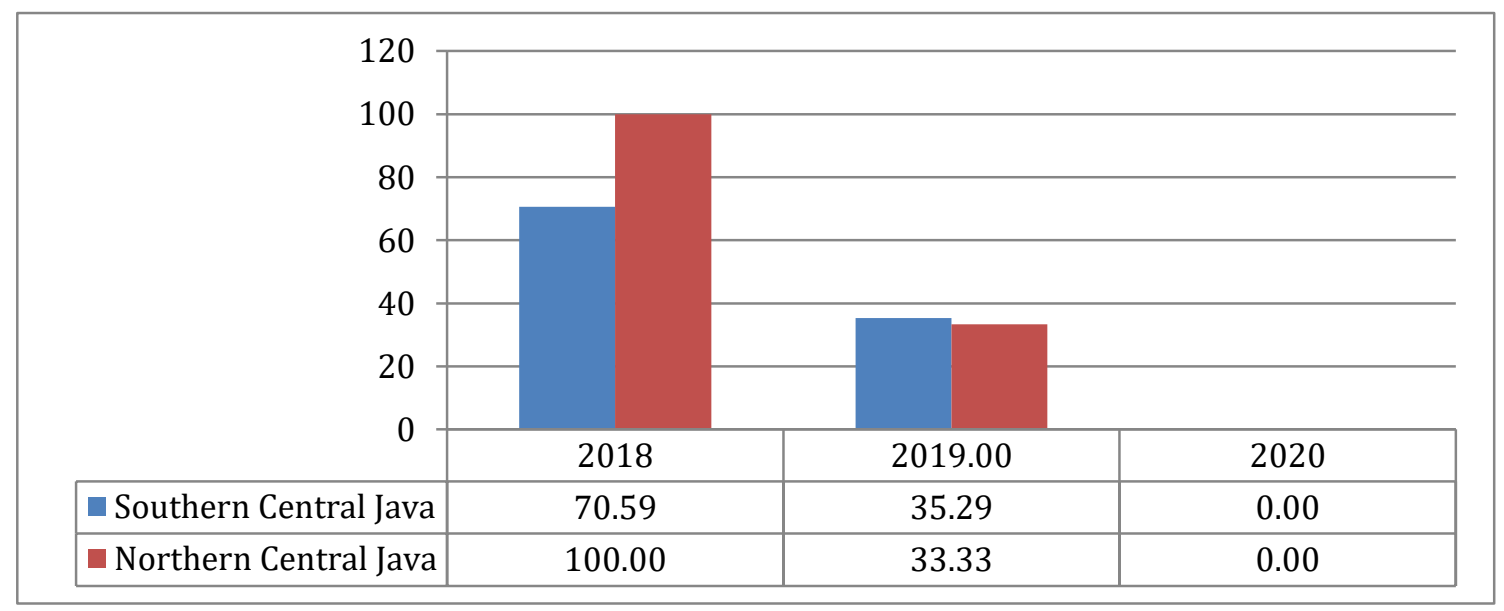

Figure 2. Percentage of the Number of Districts that Have Inclusive Growth Against

Poverty Reduction in the North and South Central Java Regions, 2018-2020

Figure 3 shows the number of districts/cities in the northern part of Central Java that has more inclusive growth towards inequality than in the southern region. In 2019, the number of districts that had inclusive organizations were balanced between the northern and southern parts of Central Java. The impact of the COVID-19 pandemic had caused all districts to had negative growth coefficient values, so that neither the north nor the south of Central Java had inclusive growth towards reducing inequality. 


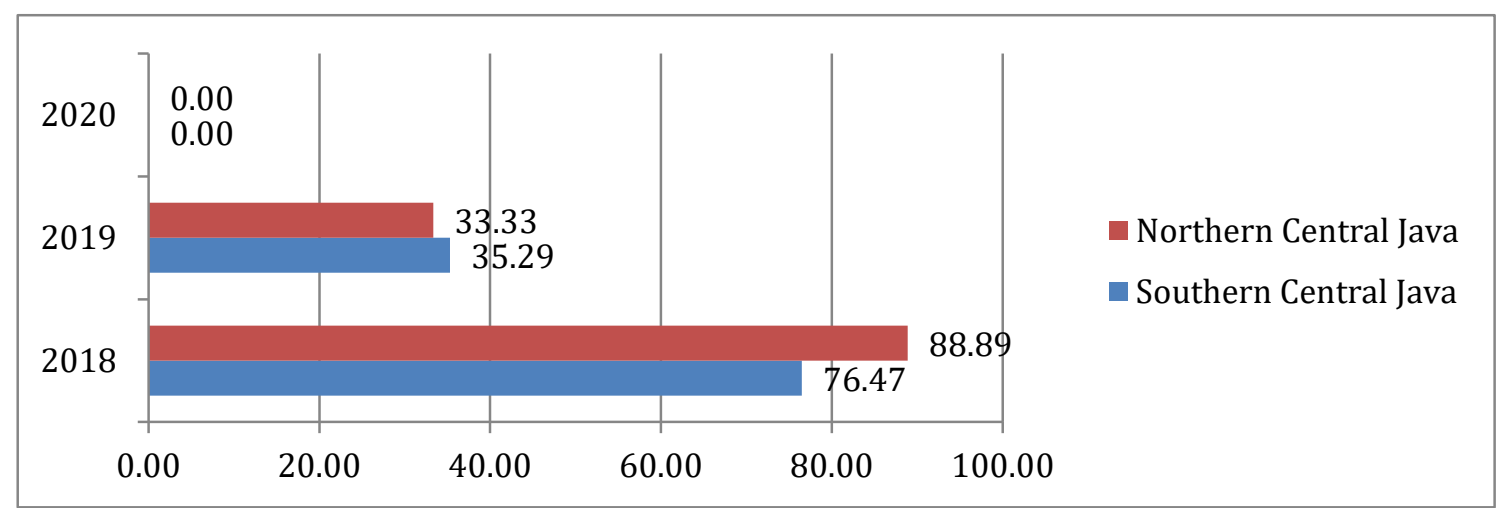

Source: Inclusive Index Coefficient Processing Results

Figure 3. Percentage of the Number of Districtsthat Have Inclusive Growth towards

Reducing Inequality in the North and South Central Java Regions, 2018-2020

Figure 4 shows that the level of inclusiveness of labor absorption during the 2018-2019 period, both in North and South Central Java, is still very minimal. This can be seen from the number of districts that had inclusive growth in labour in 2018 for the southern part of Central Java only 5,88\%, while in the northern Central Java region it was only slightly more at $16,67 \%$, while a year later the number balanced. Inclusive growth in 2020 did not occur either in the Central Java north and south due to the pandemic covid-19.

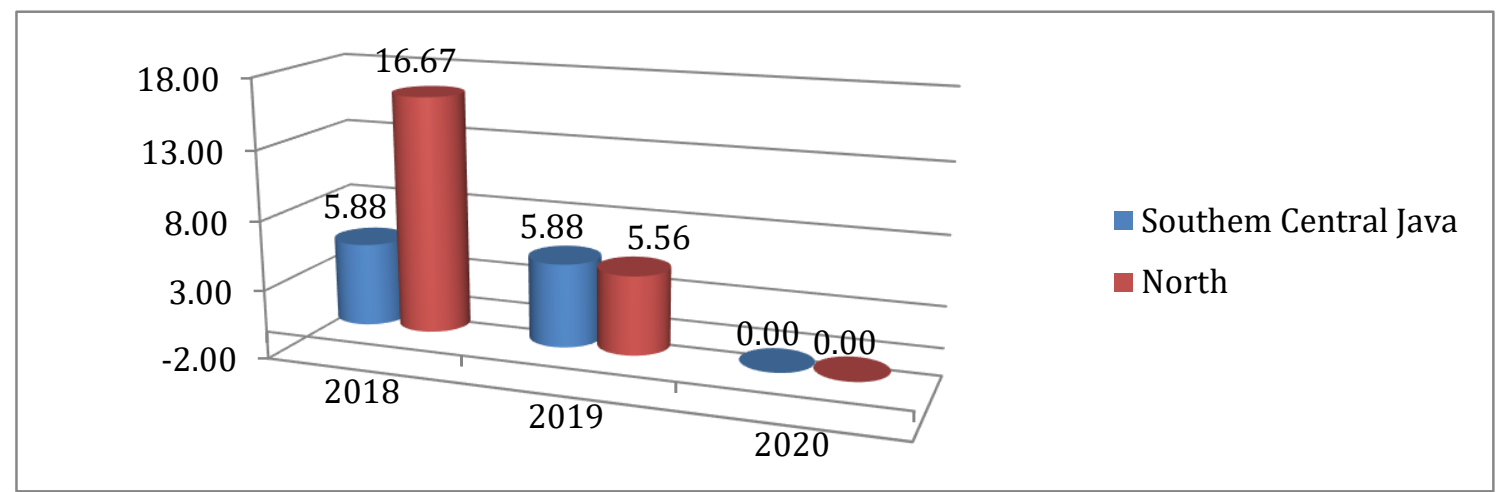

Source: Inclusive Index Coefficient Processing Results

Figure 4. Percentage of Districts with Inclusive Growth in Labour Absorption in North and South Central Java, 2018-2020

Meanwhile, research on inclusive growth in Central Java conducted by Long and Pasaribu (2019) showed that districts/cities in Central Java in 2017, adjacent areas tended to have the same level of inclusive growth. Hapsari (2019) with a different method concluded that in 2017 most districts/cities in Central Java had the inclusive growth index in the satisfactory category, only 6 districts/cities in the very satisfactory category. 


\section{Conclusion}

The results of this study indicate that in the 2018-2020 period, inclusive growth in Central Java has not been consistent with both reducing poverty, reducing inequality and employment. There are no districts/cities in Central Java that consistently have inclusive growth towards reducing poverty, reducing inequality and employment absorption during 2018-2019.

Meanwhile, the number of districts/cities that have inclusive growth towards poverty reduction in 2018-2020 is decreasing. Inclusive growth towards reducing inequality in districts/cities is also decreasing. Districts/cities that have inclusive growth in employment, are still very minimal.

In 2018, the number of regencies/cities that had inclusive growth towards reducing poverty, reducing inequality and employment absorption for the northern region was more than the southern part. Meanwhile, in 2019 the numbers were balanced for the three indicators. In 2020, the occurrence of the COVID-19 pandemic has caused economic growth to contract so that no district/city has inclusive growth for all three indicators.

Although this research is still very limited because it only uses descriptive analysis, it can provide an overview of the level of inclusiveness in Central Java and the northern and southern parts of Central Java. This research requires further studies to be able to use inferential analysis to obtain more in-depth conclusions about inclusive growth.

\section{REFERENCES}

Ahmad, Abdul A., \& Kamio Kamio. Inequality of Manufacturing Potential between North and South Regions in Central Java Province (2006 - 2007). Eko-Regional, vol. 4, no. 2, 2009

Amalina, DH, Hutagaol, MP, \& Asmara, A (2013). Inclusive Growth: The Phenomenon of Inclusive Growth in Western and Eastern Indonesia Regions. Economics and Development Policy, II (2).

Anwar, A. (2017). The Role of Human Capital on Regional Economic Growth in Java. Journal of Economia, 13(1), 79-94

Asian Development Bank. (2010). Key Indicators for Asia and the Pacific. Asian Development Bank: Mandaluyong City, Philippines.

Asian Development Bank. (2011). Framework of Inclusive Growth Indicators Key Indicators for Asia and the Pacific 2011 Special Supplement. Philippines: Asian Development Bank.

Azwar. (2016). Inclusive growth in South Sulawesi and the factors influencing it. BPPK Journal, 9(2), 216-242

Bado, Basri, Samsir, Andi, Bahansubu, Fazly, Gazali (2019) Analysis of the Quality of Economic Growth in the Province of South Sulawesi 2016. Journal of Economics and Education, XIV (2). Vol 14 No.2.

Cahyadi, NMAK, Sasongko, \& Saputra, PMA (2018). Inclusive growth and leading sector in Bali. Economic Journal of Emerging Markets, 10(1), 99-110. 
Central Java Province BPS (2021a). Poverty Line, Number, and Percentage of Poor Population in Central Java Province, 2007 - 2020. Retrieved date: July 14, 2021 from https://jateng.bps.go.id/statictable/2021/04/16/2457/garis-kemiskinan-jumlahdan percentage-penduduk-miskin-di-provinsi-jawa-tengah -2007---2020.html.

Central Java Province BPS (2021 b). Gini Ratio, 2016-2021. Retrieved date: July 14, 2021 from https://jateng.bps.go.id/indicator/23/101/1/gini-ratio-semesteran-.html.

Central Java Province BPS (2021 c). Total Labour Force 2009-20 2 0. Retrieved date: July 14, 2021 from https://jateng.bps.go.id/indicator/6/82/4/jumlah-angkatankerja.html.

Central Java Province BPS (2021 d. GRDP at 2010 Constant Prices by District/City in Central Java (Million Rupiah), 2010 - 2020. Retrieved date: July 14, 2021 from https://jateng.bps.go.id/statictable/2017/02/13/1411/-seri-2010-pdrb-atasdasar-harga-konstan-2010-menurut-kabupaten- kota-di-Jawa-Tengah-jutaanrupiah-2010---2020.html.

Central Java Province BPS (2021 e). Central Java's GRDP at 2010 Constant Prices by Field of Business (Million Rupiah), 2010-2020. Retrieved date: July 14, 2021 from https://jateng.bps.go.id/statictable/2017/11/06/1683/-seri-2010-pdrb-jawatengah-atas-dasar-harga-konstan-2010- menurut-lapangan-usaha-jutaan-rupiah2010---2020.html

Central Java Province BPS (2021 f). Percentage of Poor Population (semester) (Percent), 2006 -2021. Retrieved date: July 14, 2021 from https://jateng.bps.go.id/indicator/23/97/1/persentase-penduduk-miskinsemesteran-.html.

Central Java Province BPS (2021 g). Average Expenditure per Capita per Month on Food and Non-Food (Rupiah), 2012-2019. Retrieved date: July 14, 2021 from https://jateng.bps.go.id/indicator/5/143/1/rata-pengeluaran-per-kapita-perbulan-makanan-dan-nonmakanan.html.

Central Java BPS (2021 h). Average Monthly Food and Non-Food Expenditure per Capita in Rural Areas by District/City in Central Java Province (rupiah), 2019 and 2020. Retrieved date: July $14, \quad 2021$ from https://jateng.bps.go.id/statictable/2021/04/07/2143/rata-pengeluaran-perkapita-sebulan-maknan-dan-bukan-makanan-di-perkotaan-perdesaan-menurutkabupaten-kota-di-provinsi-jawa-tengah-rupiah-2019-dan-2020.html.

Central Java Governor Regulation Number 13 of 2019 concerning Strategic Plans for Central Java Province Regional Apparatuses for 2018-2023.

Fitri, Nursa, Zakaria, Junaidin \& Hasbi (2021). Analysis of Economic Growth and Income Disparities on Welfare Between Regencies/Cities in South Sulawesi Province 20052019. Journal of Masters in Management, Indonesian Muslim University. Vol.8. Number 1.

Hapsari, Wulan Retno (2019). Analysis of Regency/City Inclusive Economic Growth in Central Java. Sukowati Research and Development Journal, 3(1), 106-116.

Hidayat, Ibnu, Mulatsih, Sri \& Rindayati, Wiwiek (2020). The Determinants of Inclusive Economic Growth in Yogyakarta. Journal of Economics, Vol. 16,No. 2

Iskandar, Azwar (2016). The Inclusive Growth in South Sulawesi and Its Determinants. BPKP Journal. Vol 9. No 2.

Klasen, Stephen. 2010. Measuring and Monitoring Inclusive Growth: Multiple Definitions, Open Questions, and Some Constructive Proposals. ADB Sustainable Development Working Paper Series. 
Kusumaningrum, Saputri and Yuhan, Risno Julaeni (2019). Provincial Economic Growth in Indonesia Based on the Composite Index of Inclusive Economic Growth and the Factors Affecting It. Journal of Economics and Public Policy, 10(1), 1-17.

Lisna, V., Sinaga, B. M., Firdaus, M., \& Sutomo, S. (2013). Impact of Fiscal Capacity on Poverty Reduction: An Analysis of Policy Simulation. Indonesian Journal of Economics and Development, 14(1), 1-26

McKinley, Terry. (2010). Inclusive Growth Criteria and Indicators: an Inclusive Growth Index for Country Progress. ADB Sustainable Development Working Paper Series, No. 14, June 2010.

Munir, F., \& Ullah, S. (2018). Inclusive Growth in Pakistan : Measurement and Determinants. The Pakistan Journal of Social Issues, Special Issue, 150-162.

Nalle, Frederic Winston. (2018). Analysis of Inclusive Economic Growth in North Central Timor Regency. Journal of Dry Land Agribusiness. Vol.3 No.3.

Nur, I., Mulatsih, S., \& Asmara, A. (2013). Analysis of Economic Structure and Factors Affecting South Sumatra Economic Growth. Journal of Economics and Development Policy, 2(1), 47-59.

Prasetyo, B. A., Priyarsono, D. S., \& Mulatsih, S. (2013). Infrastructure, Economic Growth, And Inequality In Indonesia Land Borders. Economic Journal of Emerging Markets, 5(2), 99-108.

Prasetyantoko, A., Budiantoro, S., \& Bahagijo, S. (2012). Inclusive development: Indonesia's prospects and challenges. Jakarta: LP3ES: Initiative.

Purwanti, S., \& Rahmawati, F. (2021). The Effect of Government Expenditure and Open Unlabour Rate (TPT) on Indonesia's Inclusive Economic Growth. Ecoplan, 4(1), 32-44.

Quy, N. H. (2016). Relationship between Economic Growth, Unemployment and Poverty: Analysis at Provincial Level in Vietnam. International Journal of Economics and Finance, 8(12), 113-119.

Rambeli, N. B., Marikan, D. A. A., \& Hashim, E. (2016). The Effect of Foreign Direct Investment, Exports and Employment on Economic Growth Model. International Journal of Academic Research in Business and Social Sciences, 6(11), 361-376.

Ramadhan, Reza Rizki and Setiadi Yaya (2019). Effect of Physical Capital and Human Resources on the Inclusive Index in Indonesia. Journal of Development Economics, $17(2), 109-124$.

Rindayati, W., Hutagaol, M. P., \& Siregar, H. (2007). The Impact of Fiscal Decentralization on Regional Fiscal Performance and Food Security in the Province of West Java. Journal of Management and Agribusiness, 4(2), 103-117.

Septiani (2020). The Role of Efforts Forward Success Together (Msb) in Supporting Inclusive Economic Growth. Scientific Journal of Business Economics. No. 25 Vol 2.

Sholihah, Dyah Hapsari Amalina. (2014). Inclusive Growth: Influencing Factors and Their Impact on Middle Class Growth in Indonesia. Bogor Agricultural University Thesis. Bogor. 97 pp.

Sipahutar, M. A., Oktaviani, R., Siregar, H., \& Juanda, B. (2016). Effects of Credit on Economic Growth, Unemployment and Poverty. Journal of Development Economics: Study of Economics and Development Problems, 17(1), 37-49.

Sitorus, Agnes Vera Yanti and Arsani, Ade Marsinta (2016). Comparison of Inclusive Economic Growth in 33 Provinces of Indonesia 2010-2015: Case Study Using ADB, WEF, AND UNDP Approach Methods. Journal of Development Planning. 64-77

Sugiyono. (2014). Educational Research Methods Quantitative, Qualitative, and R\&D Approaches. Bandung: Alphabeta. 
Sukanto, S. (2015). The Phenomenon of Inflation, Unemployment And Economic Growth In Indonesia: The Philips Curve Approach And Okun's Law. Journal of Development Economics, 13(2), 96-106.

Sulistyowati, N., Sinaga, B. M., \& Novindra, N. (2017). Impacts of Government and Household Expenditure on Human Development Index. Journal of Jejak, 10(2), 412-428.

Sungkar, S. N., Nazamuddin, \& Nasir, M. (2015). Effect of Minimum Wage on Income Inequality in Indonesia. Journal of Economics, 3(2), 40-53.

Suryanarayana, MH 2008. Inclusive Growth: What is so exclusive about it?. Indira Gandhi Institute of Development Research, Mumbai.

Trenasia.com (2020). Ganjar Reveals Reasons for Industrial Inequality in South and North Central Java. Retrieved date: August 12,2021 from https://www.trenasia.com/ganjar-ungkap-alasan-ketimpangan-industri-di-selatandan-utara-jateng

Wahyuni, I. G. A. P., Sukarsa, M., \& Yuliarmi, N. (2014). The Effect of Government Expenditures and Investments on Economic Growth and Income Gap in Districts/Cities in Bali Province. E-Journal of Economics and Business, Udayana University, 3(8), 91-101.

Warsilah, Henny (2015). Inclusive Development as an Effort to Reduce Urban Social Exclusion: The Case of Marginalized Groups in Semanggi Village, Solo, Central Java. Journal of Society \& Culture, Volume 17 No. 2.

Wibowo, D. A. (2014). The Effect of Education Financing, Education Level, Economic Growth and Poverty in Central Java. Journal of Economia, 10(2), 133-140.

Wirawan, I. M. T., \& Arka, S. (2015). Analysis of the Effect of Education, GRDP Per Capita and Unemployment Rate on the Number of Poor People in Bali Province. EJurnal EP Unud, $4(5), 546-560$ 
Appendix 1. Coefficient of Growth Inclusiveness in Reducing Poverty, Reducing Inequality, Absorption of Labour and Coefficient of Economic Growth in 35 Districts at Central Java, 2018

\begin{tabular}{|c|c|c|c|c|}
\hline Districts & IGp & IGin & IGem & Gg \\
\hline Cilacap & 0,05 & 0,05 & $-0,04$ & 0,03 \\
\hline Banyumas & 0,18 & 0,18 & 0,06 & 0,06 \\
\hline Purbalingga & 0,07 & 0,07 & 0,01 & 0,05 \\
\hline Banjarnegara & 0,15 & 0,15 & 0,03 & 0,06 \\
\hline Kebumen & $-0,04$ & $-0,04$ & 0,00 & 0,05 \\
\hline Purworejo & 0,13 & 0,13 & 0,05 & 0,05 \\
\hline Wonosobo & 0,28 & 0,28 & 0,02 & 0,05 \\
\hline Magelang & 0,20 & 0,20 & $-0,02$ & 0,05 \\
\hline Boyolali & 0,20 & 0,20 & 0,05 & 0,06 \\
\hline Klaten & 0,05 & 0,05 & 0,01 & 0,05 \\
\hline Sukoharjo & 0,07 & 0,07 & 0,03 & 0,06 \\
\hline Wonogiri & 0,32 & 0,32 & 0,06 & 0,05 \\
\hline Karanganyar & 0,12 & 0,12 & 0,02 & 0,06 \\
\hline Sragen & 0,03 & 0,03 & $-0,04$ & 0,06 \\
\hline Grobogan & 0,02 & 0,02 & 0,00 & 0,06 \\
\hline Blora & $-0,02$ & $-0,02$ & 0,05 & 0,04 \\
\hline Rembang & 0,12 & 0,12 & $-0,03$ & 0,06 \\
\hline Pati & 0,11 & 0,11 & 0,01 & 0,06 \\
\hline Kudus & 0,14 & 0,14 & 0,03 & 0,03 \\
\hline Jepara & 0,12 & 0,12 & 0,01 & 0,06 \\
\hline Demak & 0,24 & 0,24 & 0,07 & 0,05 \\
\hline Semarang & 0,07 & 0,07 & $-0,03$ & 0,06 \\
\hline Temanggung & 0,04 & 0,04 & 0,01 & 0,05 \\
\hline Kendal & 0,12 & 0,12 & 0,01 & 0,06 \\
\hline Batang & 0,12 & 0,12 & 0,06 & 0,06 \\
\hline Pekalongan & 0,21 & 0,21 & 0,01 & 0,06 \\
\hline Pemalang & 0,03 & 0,03 & 0,01 & 0,06 \\
\hline Tegal & 0,06 & 0,06 & 0,00 & 0,05 \\
\hline Brebes & 0,12 & 0,12 & 0,01 & 0,05 \\
\hline Kota Magelang & 0,06 & 0,06 & 0,06 & 0,05 \\
\hline Surakarta & 0,29 & 0,29 & 0,01 & 0,06 \\
\hline Salatiga & 0,22 & 0,22 & 0,04 & 0,06 \\
\hline Kota Semarang & 0,21 & 0,21 & $-0,03$ & 0,06 \\
\hline Kota Pekalongan & 0,19 & 0,19 & 0,03 & 0,06 \\
\hline Kota Tegal & 0,06 & 0,06 & 0,00 & 0,06 \\
\hline Jawa Tengah & 0,11 & $\mathbf{0 , 1 1}$ & $\mathbf{0 , 0 1}$ & 0,05 \\
\hline
\end{tabular}

Source: Results of District Inclusiveness Coefficient,2018 
Appendix 2. Coefficient of Growth Inclusiveness in Reducing Poverty, Reducing Inequality, Absorption of Labour and Coefficient of Economic Growth in 35 Districts at Central Java, 2019

\begin{tabular}{|c|c|c|c|c|}
\hline Districts & IGp & IGin & IGem & Gg \\
\hline Cilacap & 0,08 & 0,08 & 0,05 & 0,02 \\
\hline Banyumas & 0,04 & 0,04 & 0,01 & 0,06 \\
\hline Purbalingga & 0,05 & 0,05 & $-0,02$ & 0,05 \\
\hline Banjarnegara & 0,09 & 0,09 & $-0,02$ & 0,05 \\
\hline Kebumen & 0,10 & 0,10 & 0,05 & 0,05 \\
\hline Purworejo & $-0,06$ & $-0,06$ & 0,00 & 0,05 \\
\hline Wonosobo & $-0,04$ & $-0,04$ & 0,00 & 0,05 \\
\hline Magelang & 0,10 & 0,10 & 0,06 & 0,05 \\
\hline Boyolali & $-0,03$ & $-0,03$ & 0,01 & 0,06 \\
\hline Klaten & 0,04 & 0,04 & 0,04 & 0,05 \\
\hline Sukoharjo & 0,18 & 0,18 & 0,01 & 0,06 \\
\hline Wonogiri & $-0,13$ & $-0,13$ & $-0,07$ & 0,05 \\
\hline Karanganyar & 0,05 & 0,05 & 0,01 & 0,06 \\
\hline Sragen & $-0,09$ & $-0,09$ & 0,01 & 0,06 \\
\hline Grobogan & 0,01 & 0,01 & $-0,01$ & 0,05 \\
\hline Blora & 0,23 & 0,23 & $-0,06$ & 0,04 \\
\hline Rembang & 0,07 & 0,07 & $-0,01$ & 0,05 \\
\hline Pati & $-0,04$ & $-0,04$ & 0,00 & 0,06 \\
\hline Kudus & 0,02 & 0,02 & 0,01 & 0,03 \\
\hline Jepara & 0,10 & 0,10 & 0,01 & 0,06 \\
\hline Demak & 0,08 & 0,08 & $-0,03$ & 0,05 \\
\hline Semarang & $-0,05$ & $-0,05$ & 0,05 & 0,05 \\
\hline Temanggung & 0,08 & 0,08 & 0,04 & 0,05 \\
\hline Kendal & 0,10 & 0,10 & 0,03 & 0,06 \\
\hline Batang & $-0,04$ & $-0,04$ & $-0,01$ & 0,05 \\
\hline Pekalongan & $-0,06$ & $-0,06$ & 0,02 & 0,05 \\
\hline Pemalang & $-0,01$ & $-0,01$ & 0,02 & 0,06 \\
\hline Tegal & 0,02 & 0,02 & 0,02 & 0,05 \\
\hline Brebes & $-0,05$ & $-0,05$ & $-0,01$ & 0,06 \\
\hline Kota Magelang & 0,20 & 0,20 & $-0,05$ & 0,05 \\
\hline Surakarta & 0,03 & 0,03 & 0,05 & 0,06 \\
\hline Salatiga & 0,02 & 0,02 & $-0,06$ & 0,06 \\
\hline Kota Semarang & $-0,07$ & $-0,07$ & 0,03 & 0,07 \\
\hline Kota Pekalongan & $-0,02$ & $-0,02$ & 0,04 & 0,05 \\
\hline Kota Tegal & $-0,04$ & $-0,04$ & 0,07 & 0,06 \\
\hline Jawa Tengah & 0,02 & 0,02 & $\mathbf{0 , 0 1}$ & 0,05 \\
\hline
\end{tabular}

Source: Results of District Inclusiveness Coefficient,2019 
Appendix 3. Coefficient of Growth Inclusiveness in Reducing Poverty, Reducing Inequality, Absorption of Labour and Coefficient of Economic Growth in 35 Districts at Central Java, 2020

\begin{tabular}{|c|c|c|c|c|}
\hline Districts & IGp & IGin & IGem & Gg \\
\hline Cilacap & 0,15 & 0,15 & 0,04 & $-0,11$ \\
\hline Banyumas & $-0,15$ & $-0,15$ & 0,00 & $-0,02$ \\
\hline Purbalingga & 0,14 & 0,14 & 0,04 & $-0,01$ \\
\hline Banjarnegara & 0,01 & 0,01 & 0,00 & $-0,01$ \\
\hline Kebumen & 0,10 & 0,10 & 0,02 & $-0,01$ \\
\hline Purworejo & 0,09 & 0,09 & 0,05 & $-0,02$ \\
\hline Wonosobo & 0,02 & 0,02 & 0,00 & $-0,02$ \\
\hline Magelang & 0,10 & 0,10 & 0,04 & $-0,02$ \\
\hline Boyolali & 0,07 & 0,07 & 0,04 & $-0,01$ \\
\hline Klaten & 0,20 & 0,20 & $-0,01$ & $-0,01$ \\
\hline Sukoharjo & $-0,31$ & $-0,31$ & 0,01 & $-0,02$ \\
\hline Wonogiri & 0,29 & 0,29 & 0,07 & $-0,01$ \\
\hline Karanganyar & 0,11 & 0,11 & 0,06 & $-0,02$ \\
\hline Sragen & $-0,06$ & $-0,06$ & 0,02 & $-0,02$ \\
\hline Grobogan & 0,19 & 0,19 & 0,02 & $-0,02$ \\
\hline Blora & 0,05 & 0,05 & 0,05 & $-0,05$ \\
\hline Rembang & 0,09 & 0,09 & $-0,01$ & $-0,02$ \\
\hline Pati & 0,08 & 0,08 & $-0,03$ & $-0,01$ \\
\hline Kudus & $-0,14$ & $-0,14$ & 0,05 & $-0,04$ \\
\hline Jepara & 0,27 & 0,27 & 0,04 & $-0,02$ \\
\hline Demak & 0,03 & 0,03 & 0,04 & 0,00 \\
\hline Semarang & $-0,19$ & $-0,19$ & 0,02 & $-0,03$ \\
\hline Temanggung & 0,36 & 0,36 & $-0,25$ & $-0,02$ \\
\hline Kendal & $-0,07$ & $-0,07$ & 0,05 & $-0,02$ \\
\hline Batang & 0,17 & 0,17 & 0,03 & $-0,01$ \\
\hline Pekalongan & 0,05 & 0,05 & 0,01 & $-0,02$ \\
\hline Pemalang & 0,14 & 0,14 & 0,00 & $-0,01$ \\
\hline Tegal & 0,01 & 0,01 & 0,01 & $-0,01$ \\
\hline Brebes & 0,46 & 0,46 & 0,02 & $-0,01$ \\
\hline Kota Magelang & 0,18 & 0,18 & 0,04 & $-0,02$ \\
\hline Surakarta & 0,02 & 0,02 & 0,00 & $-0,02$ \\
\hline Salatiga & 0,10 & 0,10 & 0,06 & $-0,02$ \\
\hline Kota Semarang & $-0,36$ & $-0,36$ & 0,06 & $-0,02$ \\
\hline Kota Pekalongan & 0,34 & 0,34 & $-0,08$ & $-0,02$ \\
\hline Kota Tegal & $-0,18$ & $-0,18$ & $-0,07$ & $-0,02$ \\
\hline Jawa Tengah & $-0,06$ & $-0,06$ & 0,02 & $-0,03$ \\
\hline
\end{tabular}

Source: Results of District Inclusiveness Coefficient,2020 